E-ISSN : 2549-6581

Artikel Hasil Penelitian

Diterima : 15 Maret 2018

Direview : 21 Maret 2018

Dimuat : April - Juli 2018

\section{OPEN ACCESS}

Journal of Issues in Midwifer

\title{
Pola Asuh Dengan Terjadinya Picky Eater (Pilih-Pilih Makanan) Pada Anak Usia 3-6 Tahun Di Dusun Sumberaji Desa Karangjeruk Kecamatan Jatirejo Kabupaten Mojokerto
}

\author{
Zulfa Rufaida $^{1^{*}}$, Sri Wardini Puji Lestari ${ }^{1}$ \\ ${ }^{1}$ Sekolah Tinggi IImu Kesehatan Majapahit Mojokerto Prodi D3 Kebidanan \\ Email*:zulfarufaida@gmail.com \\ Tlp : +6285649747049
}

\begin{abstract}
Picky eater is a child's behavior is unwilling or refuses to eat, or have difficulty consuming the food. Picky eater influenced by upbringing, feeding behavior of parents, the mother and child interaction, exclusive breastfeeding, solids, and psychological and physical condition of the child. Picky eater can cause children micro- and macronutrient deficiencies that ultimately interfere with the physical and psychological growth. The aim of research to determine the relationship of parenting parents against the picky eater in children aged 3-6 years

The study design cross sectional observational analytic types. Population mothers of children aged 3-6 years in Dusun Sumberaji Desa Karangjeruk Kecamatan Jatirejo Kabupaten Mojokerto. Sample 41 respondents drawn using sampling techniques Non - Probability sampling, kind of total sampling. Retrieval of data held on December $18^{\text {th }} 2017$ - January 05 ${ }^{\text {th }}$ 2018, the research instruments using a questionnaire with interview techniques. Data analysis used Fisher exact test, $\alpha$ $=0.05$.

The results showed that the average of respondent who had democratic parenting style was as many as 22 respondents (64.7\%) with a child who experienced picky eater.

Results count the Fisher exact test test obtained exact sig value (2-sided) 0.401 meant that Ho accepted,there is no relationship between parenting style of parenst to theincidentof picky eater in children used 3-6 years.

Conclusions democratic parenting style adopted by parents still can not make children become picky eater so it needs to pay attention to the physical condition of the child. Parents are expected to vary the diet so that children are more interested in eating food.
\end{abstract}

Keywords: Parenting, Picky Eater

\section{ABSTRAK}

Pilih-pilih makanan (picky eater) adalah perilaku anak tidak mau atau menolak untuk makan, atau mengalami kesulitan mengkonsumsi makanan. Picky eaterdipengaruhi oleh pola asuh, perilaku 
makan orang tua, interaksi ibu dan anak, pemberian ASI eksklusif, MPASI, dan psikologis serta kondisi fisik anak. Picky eater dapat menyebabkan anak kekurangan mikro dan makronutrien yang akhirnya mengganggu pertumbuhan fisik dan psikologis. Tujuan penelitian untuk mengetahui hubunganpolaasuh orang tuaterhadapterjadinyapicky eaterpadaanakusia 3-6 tahun Desain penelitian observational analytic jenis cross sectional. Populasi ibu yang memiliki anak usia 3-6 tahun di Dusun Sumberaji Desa Karangjeruk Kecamatan Jatirejo Kabupaten Mojokerto. Sampel 41 responden diambil menggunakan teknik sampling Non - Probability sampling, jenis total sampling. Pengambilan data dilaksanakan pada tanggal 18 Desember 2017 - 05 Januari 2018, instrumen penelitian menggunakan kuesioner dengan teknik wawancara. Analisis data menggunakan uji Fisher exact test, $\alpha=0,05$. Hasil penelitian bahwa rata-rata responden berpola asuh demokratis sebanyak 22 responden (64.7\%) dengan anak mengalami picky eater. Hasil hitungan uji Fisher exact test didapatkan nilai exact sig (2-sided) 0.401 artinya Ho diterima tidak ada hubungan pola asuh orang tua terhadap terjadinya picky eater pada anak usia 3-6 tahun. Simpulan pola asuh demokratis yang diterapkan oleh orangtua masih belum bisa membuat anak menjadi tidak picky eater sehingga perlu memperhatikan kondisi fisik anak. Orang tua diharapkan memvariasikan menu makanan sehingga anak lebih berminat untuk mengkonsumsi makanan.

Kata kunci: pola Asuh, Picky Eater (Pilih-pilih makanan)

1Korespondensi: Zulfa Rufaida. Surel: zulfarufaida@gmail.com 


\section{PENDAHULUAN}

Picky eater (kesulitan makan) adalah perilaku anak tidak mau atau menolak untuk makan, atau mengalami kesulitan mengkonsumsi makanan atau minuman dengan jenis dan jumlah sesuai usia secara fisiologis (alamiah dan wajar), yaitu mulai dari membuka mulutnya tanpa paksaan, mengunyah, menelan, hingga sampai terserap di pencernaan secara baik tanpa paksaan dan tanpa pemberian vitamin dan obat tertentu ${ }^{1}$.

Studi populasi di London, Inggris, anak berumur 3 tahun 17\% digambarkan memiliki nafsu makan yang buruk dan $12 \%$ picky eater. Prevalensi picky eater di Indonesia terjadi pada anak sekitar $20 \%$, dari anak picky eater $44,5 \%$ mengalami malnutrisi ringan sampai sedang, dan $79,2 \%$ dari subjek penelitian telah mengalami picky eater lebih dari 3 bulan².

Memilih-milih makanan (picky eater) merupakan masalah pada anak yang perlu diperhatikan baik oleh orang tua maupun praktisi kesehatan, karena picky eater pada anak memiliki efek yang merugikan, baik bagi pengasuh ataupun anak itu sendiri. Picky eater banyak terjadi pada umur 1 sampai 3 tahun dan berisiko dua kali lebih besar untuk mempunyai berat badan rendah pada umur 4,5 tahun dibandingkan anak yang bukan picky eater ${ }^{2}$ Masalah pola makan yang sering terjadi pada anak balita seperti picky eater dan penanganan yang salah terhadap perilaku picky eater oleh orang tua merupakan salah satu penyumbang peningkatan status gizi kurang maupun gizi buruk pada anak Indonesia ${ }^{2}$. Pengasuh anak dengan karakteristik tertentu mempunyai dampak positif pada keadaan gizi anak. lbu dari anak yang bergizi, merupakan ibu yang terampil mengurus anak, sabar, dan tampak dewasa dibandingkan ibu dari kelompok dengan anak bergizi rendah. Orang tua banyak mempengaruhi perkembangan pola makan pada anak. Studi kuantitatif yang dipublikasikan tahun 1998 menguji pemilihan makan pada batita yang berhubungan dengan pemilihan makan anggota keluarganya. Penelitian lain juga menunjukkan bahwa praktek pemberian makan yang salah dari orang tua atau karena kurang pengalaman dapat menyebabkan anak gagal tumbuh'.

Penanganan pada masalah makanan anak meliputi training untuk orang tua, pendidikan gizi, latihan berinteraksi, dan kemampuan dalam menyediakan makanan. Selain itu, cara yang terbaikya itu mengenali penyebab kesulitan makan dan mengatasi penyebabnya secara langsung dan menyeluruh ${ }^{1}$. Tujuan penelitian ini adalah untuk mengetahui hubungan pola asuh orang tua terhadap terjadinya picky eater (pilih-pilih makanan) pada anak usia 3-6 tahun.

\section{METODE PENELITIAN}

\section{Rancangan/Desain Penelitian}

Penelitian ini menggunakan metode pendekatan cross sectional.

\section{Sumber Data}

Variabel independent adalah Pola asuh, merupakan data primer dengan alat ukur kuesioner yang dibuat peneliti.

Variabel dependent adalah picky eater, data primer ayng 
diambil dengan kuesioner yang dibuat peneliti.

\section{Sasaran Penelitian}

Populasi dalam penelitian ini adalah seluruh orang tua yang mempunyai anak usia 3-6 tahun di Dusun Sumberaji Desa Karangjeruk Kecamatan Jatirejo Kabupaten Mojokerto.

Sampel yang digunakan dalam penelitian ini adalah seluruh anggota populasi yaitu orang tua yang mempunyai anak usia 3-6 tahun di Dusun Sumberaji Desa Karangjeruk Kecamatan Jatirejo Kabupaten Mojokerto sebanyak 41 ibu dan anak.

Sampling dalam penelitian ini adalah metode Non - Probability sampling yaitu menggunakan teknik total sampling. Pengembangan Instrumen dan
Teknik Pengumpulan Data

Instrumen penelitian yang digunakan dalam penelitian ini adalah kuesioner dengan menggunakan skala Guttman. Kuesioner yang disajikan dalam daftar pertanyaan yang sudah tersusun dengan baik dimana responden tinggal memberi tanda tertentu. Dimana kuesioner tentang pola asuh dibuat berdasarkan dari sumber pustaka ${ }^{3}$. Sedangkan picky eater menggunakan teknik wawancara terstruktur yang dibuat sendiri oleh peneliti dan belum diuji validitasnya.

Pengumpulan data pada penelitian ini menggunakan data primer, peneliti mengajukan pendekatan kepada calon responden untuk bersedia menjadi responden sebagai objek penelitian. Teknik yang digunakan adalah teknik wawancara terstruktur. Pada saat Posyandu balita peneliti mengumpulkan responden ke dalam satu ruangan kemudian mulai membagikan kuesioner tentang pola asuh. Peneliti juga melakukan wawancara untuk melengkapi lembar checklist picky eater.

\section{Teknik Analisis Data}

Analisis data dilakukan dengan tiga tahap, meliputi analisis univariat dengan prosentase. Analisis bivariat dengan uji statistik yang digunakan adalah uji Chi Square digunakan untuk mengetahui adanya hubungan pola asuh orang tua terhadap terjadinya picky eater (pilih-pilih makanan) pada anak usia 3-6 tahun dengan datanya berbentuk nominal dan taraf signifikasi yang digunakan adalah $\alpha=0.05$. Karena uji chi square tidak memenuhi, sehingga menggunakan uji fisher exact test dengan rumus:

$$
P(a . b . c . d)=\frac{(a+b) !(c+d) !(a+c) !(b+d) !}{n ! a ! b ! c ! d !}
$$

\section{HASIL PENELITIAN}

\section{Data Umum}

1. Karakteristik Responden Berdasarkan Umur Tabel 1. Distribusi Frekuensi Responden Berdasarkan Umur

\begin{tabular}{|c|l|c|c|}
\hline No & Umur & Frekuensi & $\begin{array}{c}\text { Presentase } \\
(\%)\end{array}$ \\
\hline 1 & $<20$ & 0 & 0 \\
2 & Tahun & 25 & 61 \\
3 & $20-35$ & 16 & 39 \\
& Tahun & & \\
& $>35$ & & \\
& Tahun & & $\mathbf{1 0 0}$ \\
\hline \multicolumn{2}{|c|}{ Jumlah } & $\mathbf{4 1}$ & \multicolumn{1}{|c|}{ didapatkan } \\
\hline \multicolumn{2}{|c|}{ Terdasarkan tabel 1 }
\end{tabular}

Berdasarkan tabel 1 didapatkan bahwa rata-rata responden berumur 20-35 tahun sebanyak 25 responden (61\%). 


\section{Karakteristik Responden} Berdasarkan Jumlah Anak

Tabel 2 Distribusi Frekuensi

Responden Berdasarkan Jumlah Anak

\begin{tabular}{|c|c|c|c|}
\hline $\begin{array}{l}\mathbf{N} \\
\mathbf{0}\end{array}$ & $\begin{array}{l}\text { Jumla } \\
\text { h Anak }\end{array}$ & $\begin{array}{c}\text { Frekuens } \\
\text { i }\end{array}$ & $\begin{array}{c}\text { Presentas } \\
\text { e (\%) }\end{array}$ \\
\hline 1 & $1-2$ & 34 & 82.9 \\
\hline 2 & Orang & 7 & 17.1 \\
\hline 3 & $\begin{array}{l}3-4 \\
\text { Orang } \\
>5 \\
\text { Orang }\end{array}$ & 0 & 0 \\
\hline \multicolumn{2}{|c|}{ Jumlah } & 41 & 100 \\
\hline
\end{tabular}

Berdasarkan tabel 2 didapatkan bahwa sebagian besar responden mempunyai anak 1-2 orang sebanyak 34 responden (82.9\%).

\section{Karakteristik Responden} Berdasarkan Pendidikan Tabel 3. Distribusi Frekuensi Responden Berdasakan Pendidikan

\begin{tabular}{|c|l|c|c|}
\hline No & Pendidikan & Frekuensi & $\begin{array}{c}\text { Present } \\
\text { ase (\%) }\end{array}$ \\
\hline 1 & SD & 5 & 12.2 \\
2 & SLTP & 10 & 24.4 \\
3 & SLTA & 19 & 46.3 \\
4 & Akademi/PT & 7 & 17.1 \\
5 & Tidak & 0 & 0 \\
& Sekolah & & $\mathbf{1 0 0}$ \\
\hline \multicolumn{2}{|c|}{ Jumlah } & $\mathbf{4 1}$ & $\mathbf{1 0 0}$ \\
\hline
\end{tabular}

Berdasarkan tabel 3 didapatkan bahwa sebagian kecil responden berpendidikan SLTA sebanyak 19 responden $(46.3 \%)$.

\section{Karakteristik Responden Berdasarkan Pekerjaan}

Tabel 4. Distribusi Frekuensi Responden Berdasarkan Pekerjaan

\begin{tabular}{|c|l|c|c|}
\hline $\begin{array}{c}\text { N } \\
\text { o }\end{array}$ & $\begin{array}{c}\text { Pekerja } \\
\text { an }\end{array}$ & $\begin{array}{c}\text { Frekue } \\
\text { nsi }\end{array}$ & $\begin{array}{c}\text { Presenta } \\
\text { se (\%) }\end{array}$ \\
\hline 1 & Bekerja & 14 & 34.1 \\
2 & Tidak & 27 & 65.9 \\
& Bekerja & & \\
\hline \multicolumn{2}{|c|}{ Jumlah } & $\mathbf{4 1}$ & $\mathbf{1 0 0}$ \\
\hline
\end{tabular}

Berdasarkan tabel 4 didapatkan bahwa rata-rata responden tidak bekerja yaitu sebanyak 27 responden (58.5\%).

Data Khusus (Arial 12, spasi 1, Huruf Besar Kecil)

1. Pola Asuh Orang Tua Tabel 5. Distribusi Frekuensi Pola Asuh Orang Tua

\begin{tabular}{|c|c|c|c|}
\hline $\begin{array}{l}\mathbf{N} \\
0\end{array}$ & $\begin{array}{l}\text { Pola } \\
\text { Asuh } \\
\text { Orang } \\
\text { Tua }\end{array}$ & $\begin{array}{l}\text { Frekuen } \\
\text { si }\end{array}$ & $\begin{array}{c}\text { Presentas } \\
\text { e (\%) }\end{array}$ \\
\hline 1 & Demokrat & 25 & 61 \\
\hline 2 & $\begin{array}{l}\text { is } \\
\text { Campura } \\
n\end{array}$ & 16 & 39 \\
\hline \multicolumn{2}{|r|}{ Jumlah } & 41 & 100 \\
\hline
\end{tabular}
bahwa rata-rata responden berpola asuh demokratis yaitu sebanyak 25 responden (61\%).

\section{Picky Eater (Pilih-Pilih}

Makanan)

Tabel 6. Distribusi Frekuensi

Picky Eater (pilih-pilih makanan)

Pada Anak Usia 3-6 Tahun

\begin{tabular}{|c|c|c|c|}
\hline No & $\begin{array}{c}\text { Picky } \\
\text { eater } \\
\text { (pilih-pilin } \\
\text { makanan) }\end{array}$ & Frekuensi & $\begin{array}{c}\text { Presentase } \\
\text { (\%) }\end{array}$ \\
\hline 1 & lya & 34 & 82.9 \\
2 & Tidak & 7 & 17.1 \\
\hline \multicolumn{1}{|c|}{ Jumlah } & $\mathbf{4 1}$ & $\mathbf{1 0 0}$ \\
\hline
\end{tabular}

Berdasarkan tabel 6 didapatkan bahwa sebagian besar responden mengalami picky eater (pilih-pilih makanan) yaitu sebanyak 34 responden (82.9\%).

3. Tabulasi Silang

Tabel 7. Tabulasi Silang Antara

Pola Asuh Dengan Terjadinya

Picky Eater (Pilih-Pilih Makanan) Pada Anak Usia 3-6 Tahun

\begin{tabular}{|l|l|l|l|l|l|l|l|}
\hline \multirow{2}{*}{$\mathbf{N}$} & \multirow{2}{*}{$\begin{array}{c}\text { Pola } \\
\text { o }\end{array}$} & \multicolumn{3}{|c|}{ Picky Eater } & \multirow{2}{*}{ Jumlah } \\
\cline { 3 - 6 } & asuh & Ya & Tidak & & \\
\cline { 3 - 6 } & & F & $\%$ & F & $\%$ & F & $\%$ \\
\hline
\end{tabular}




\begin{tabular}{|c|l|c|c|c|c|c|c|}
\hline 1 & Demokratis & 22 & 64.7 & 3 & 42.9 & 25 & 61 \\
\hline 2 & Campuran & 12 & 35.3 & 4 & 57.1 & 16 & 39 \\
\hline Jumlah & $\mathbf{3 4}$ & $\mathbf{1 0 0}$ & $\mathbf{7}$ & $\begin{array}{c}\mathbf{1 0} \\
\mathbf{0}\end{array}$ & $\mathbf{4 1}$ & $\begin{array}{c}\mathbf{1 0} \\
\mathbf{0}\end{array}$ \\
\hline
\end{tabular}

Berdasarkan tabel tabulasi silang 7 didapatkan bahwa rata - rata responden berpola asuh demokratis sebanyak 22 responden (64.7\%) dengan anak mengalami picky eater, dan sebagian kecil responden berpola asuh campuran sebanyak 12 responden (35.3\%) dengan anak mengalami picky eater.

Hasil hitungan uji chi square dengan tingkat kemaknaan $\alpha=0.05$ menggunakan spss 14 for windows dimana didapatkan 2 cells yang nilai ekspektasi $<5, \quad$ sehingga menggunakan fisher exact test didapatkan nilai exact sig (2-sided) 0.401 dengan tingkatan kemaknaan 0.05 yang artinya $0.401>0.05$ sehingga Ho diterima, tidak ada hubungan pola asuh terhadap terjadinya picky eater (pilih-pilih makanan) pada anak usia 3-6 tahun.

\section{PEMBAHASAN \\ Pola Asuh}

\section{Berdasarkan}

tabel 5

didapatkan dari hasil penelitian ratarata responden berpola asuh demokratis yaitu sebayak 25 responden (61\%).

Pola asuh demokratis adalah tipe pola asuh yang terbaik dari semua tipe pola asuh yang ada. Hal ini disebabkan tipe pola asuh ini selalu mendahulukan kepentingan bersama di atas kepentingan individu anak ${ }^{4}$ memprioritaskan kepentingan anak, akan tetapi tidak ragu-ragu mengendalikan mereka. Tipe pola asuh demokratis adalah tipe pola asuh yang terbaik dari semua tipe pola asuh yang ada. Hal ini disebabkan tipe pola asuh ini selalu mendahulukan kepentingan bersama di atas kepentingan individu anak ${ }^{4}$.

Pola asuh demokratis lebih banyak mempertimbangkan harapan dan pendapat anak, orang tua mendampingi anak ketika mereka membuat keputusankeputusan, sikap yang kurang baik pada anak orang tua cenderung menghadapi secara langsung dan kasar, orang tua memberikan penghargaan atau hadiah pada anak atas sikapnya yang baik, menghargai prestasi anak disekolah dan mendukung usaha anak, orang tua melarang anak untuk bertindak sendiri pada tingkat yang sesuai dengan usianya dan mengkomunikasikan peraturan pada anak secara jelas dan langsung. Dari hasil penelitian dapat dikatakan demokratis karena orang tua sangat menghargai prestasi anak dan selalu mendukung usaha dan sikap anak yang membangun dan bertanggung jawab. Jadi pola asuh yang baik dapat menciptakan karakteristik anak yang baik pula.

Pola asuh otoriter adalah tipe pola asuh orang tua yang memaksakan kehendak. Dengan tipe orang tua ini cenderung sebagai pengendali atau pengawas (controller), selalu memaksakan kehendak kepada anak, tidak terbuka terhadap pendapat anak, sangat sulit menerima saran dan cenderung memaksakan kehendak dalam perbedaan, terlalu percaya pada diri sendiri sehingga menutup katup musyawarah. Dalam upaya mempengaruhi anak sering mempergunakan pendekatan (approach) yang mengandung unsur paksaan dan ancaman. Kata-kata yang diucapkan oang tua adalah hukum atau peraturan dan tidak 
dapat diubah memonopoli tindak komunikasi dan seringkali meniadakan umpan balik dari anak ${ }^{4}$.

Pola asuh otoriter orang tua terlalu memegang kendali dan menetapkan peraturan tanpa si anak mengerti apa yang dimaksudkan orang tuanya. Orangtua memegang kendali dan menetapkan

bagaimanapun

peraturan, keadaannya, menetapkan hukuman yang dianggap adalah sikap disiplin, membuat sebagian besar keputusan pada anak tanpa ada kompromi, karena hal tersebut akan sesuai dengan tahapan perkembangan bagi anak, dan orangtua sering mengekspresikan kemarahan serta menggunakan hukuman fisik yang keras.

Umur orang tua juga dapat mempengaruhi pola asuh, hal ini dapat dilihat pada tabulasi data dimana didapatkan sebagian kecil responden berumur 20-35 tahun berpola asuh demokratis yaitu sebanyak 19 responden (46.3\%).

Umur merupakan indikator kedewasaan seseorang, semakin bertambah umur semakin bertambah pengetahuan dan pengalaman yang dimiliki mengenai perilaku yang sesuai untuk mendidik anak. Anak-anak dengan orang tua usia muda akan mendapatkan pengawasan yang lebih longgar karena dalam diri orang tua usia muda cenderung memiliki sifat toleransi yang tinggi dan memaklumi terhadap anak. Usia ibu muda juga dapat mempengaruhi sumber daya yang tersedia untuk anak $^{5}$.

Semakin tua umur seseorang semakin baik pula pola asuh yang diterapkan terhadap anak-anaknya, dan lebih mudah bagi orang tua mengetahui seberapa jauh perkembangan anak dengan pola asuh yang diterapkan oleh orang tuanya.

Bila dikaitkan dengan jumlah anak juga dapat mempengaruhi pola asuh, hal ini dapat dilihat pada tabulasi data dimana didapatkan rata-rata responden mempunyai jumlah anak 1-2 anak yaitu sebanyak 25 responden (61\%) berpola asuh demokratis.

Jumlah anak yang dimiliki keluarga akan mempengaruhi pola asuh yang diterapkan orang tua. Semakin banyak jumlah anak dalam keluarga, maka ada kecenderungan bahwa orang tua tidak begitu menerapkan pola pengasuhan secara maksimal pada anak karena perhatian dan waktunya terbagi antara anak yang satu dengan anak yang lainnya ${ }^{6}$.

Jumlah anak sangat berpengaruh dengan perkembangan anak terutama pada status gizi anak. Jika jumlah anak terlalu banyak maka orang tua tidak bisa maksimal memantau pemenuhan gizi pada anakanaknya.

Pendidikan orang tua juga dapat mempengaruhi pola asuh, hal ini dapat dilihat pada tabulasi data dimana didapatkan sebagian kecil responden berpendidikan SLTA berpola asuh demokratis yaitu sebanyak 14 responden (34.1\%).

Pendidikan berarti bimbingan atau pertolongan yang diberikan dengan sengaja terhadap anak didik oleh orang dewasa agar ia menjadi dewasa. Latar belakang pendidikan orang tua dapat mempengaruhi pola pikir orang tua baik formal maupun non formal kemudian juga berpengaruh pada aspirasi atau harapan orang tua kepada anaknya ${ }^{6}$ 
Orang tua yang berpendidikan tinggi umumnya dapat mengajarkan sopan santun kepada orang lain, baik dalam berbicara ataupun dalam hal pemantauan status gizi anak. Berbeda dengan orang tua yang mempunyai latar belakang pendidikan yang rendah, mereka akan sembarangan dalam memberikan makanan pada anak, dan akan sering menuruti kemauan anak dalam memilih makanan yang tidak sehat.

Selain umur, jumlah anak, dan pendidikan, pekerjaan juga dapat mempengaruhi pola asuh orang tua, hal ini dapat dilihat pada tabulasi data dimana didapatkan bahwa sebagian kecil responden tidak bekerja berpola asuh demokratis yaitu sebanyak 19 responden (46.3\%).

Orang tua yang bekerja terutama ibu adalah seorang ibu yang aktivitasnya melayani suami dan anak, serta ikut bekerja menambah penghasilan. Jadi, bisa dikatakan bahwa ibu yang bekerja mempunyai peran ganda yaitu mendidik anak dan bekerja. Mereka akan memiliki kepuasan hidup, punya penyesuaian diri yang bagus, memiliki harga diri yang tinggi. Dalam mendidik anak, ibu yang bekerja kurang menggunakan teknik disiplin yang keras dan otoriter, mereka lebih banyak pengertian dalam keluarganya dan anak. Selain itu, mereka akan mampu bersikap positif dalam mengatasi konflik-konflik rumah tangga, serta dapat melakukan kendali langsung terhadap permasalahan yang terjadi $^{3}$

Pola asuh yang diterapkan orang tua yang bekerja sangat berbeda dengan pola asuh orang tua yang tidak bekerja namun perkembangan yang dihasilkan tergantung dengan cara mendidik, merawat, dan mengawasi anak secara baik.

\section{Picky Eater (Pilih - Pilih Makanan)}

Berdasarkan tabel 6 didapatkan bahwa sebagian besar responden mengalami picky eater yaitu sebanyak 34 responden (82.9\%).

Kesulitan makan (picky eater) adalah perilaku anak tidak mau atau menolak untuk makan, atau mengalami kesulitan mengkonsumsi makanan atau minuman dengan jenis dan jumlah sesuai usia secara fisiologis (alamiah dan wajar), yaitu mulai dari membuka mulutnya tanpa paksaan, mengunyah, menelan, hingga sampai terserap di pencernaan secara baik tanpa paksaan dan tanpa pemberian vitamin dan obat tertentu ${ }^{1}$.

Anak akan dikatakan picky eater jika mempunyai kriteria seperti menolak makan yang konsisten terhadap makan dengan rasa, tekstur, suhu, atau bau tertentu, penolakan terhadap makanan yang baru diperkenalkan atau makanan yang pernah dikenal tetapi dengan tipe lain namun anak tidak menolak jenis makanan yang disukai, reaksi penolakan yang ditunjukkan dengan raut muka yang tidak menyenangkan,menutup mulut hingga memuntahkan makanan, terdapat riwayat traumatik pada saluran pencernaan, dan ditemukan riwayat alergi terhadap makanan atau penyakit fisik.

Anak tidak akan menjadi picky eater jika orang tua tidak selalu menuruti permintaan anak ataupun jajan sembarangan yang akan membahayakan kesehatannya 
sehingga anak cenderung mau makan jika makanan masih dalam keadaan panas dan sebaliknya anak mau makan jika makanan dingin, anak tidak pernah mempunyai riwayat traumatik pada saluran pencernaan, dan tidak mengalami kesulitan mengunyah, menghisap, menelan makanan atau hanya bisa memakan makanan lunak dan cair.

\section{Hubungan Pola Asuh Dengan Terjadinya Picky Eater (Pilih-Pilih Makanan) Pada Anak Usia 3-6 Tahun}

Berdasarkan tabel tabulasi silang 7 didapatkan bahwa rata-rata responden berpola asuh demokratis sebanyak 25 responden (61\%) dengan anak mengalami picky eater.

Hasil hitungan uji chi square dengan tingkat kemaknaan $\alpha=0.05$ menggunakan spss 14 for windows dimana didapatkan 2 cells yang nilai ekspektasi $\quad<5, \quad$ sehingga menggunakan fisher exact test didapatkan nilai exact sig (2-sided) 0.401 dengan tingkatan kemaknaan 0.05 yang artinya $0.401>0.05$ sehingga Ho diterima, tidak ada hubungan pola asuh terhadap terjadinya picky eater (pilih-pilih makanan) pada anak usia 3-6 tahun.

Hasil penelitian mendapatkan bahwa pola asuh demokratis yang diterapkan oleh orangtua masih belum bisa membuat anak menjadi tidak picky eater (pilih-pilih makanan) hal ini disebabkan karena anak cenderung yang tidak menyukai variasi makanan, kondisi fisik anak yang belum terbiasa menerima asupan makanan selain yang dia suka dan pola asuh orang tua yang tidak sepenuhnya mengasuh anak sehingga orang tua tidak sepenuhnya mengetahui kondisi anak.

\section{DAFTAR PUSTAKA}

1. Priyanah. (2008). "Gambaran Karakteristik Anak Picky Eater Yang Pernah Memeriksakan Diri Di Klinik Picky Eater Jakarta Tahun 2008". Skripsi Sarjana Kesehatan Masyarakat yang dipublikasikan. Universitas Indonesia.

2. Priyanti, sari. (2013). 'Pengaruh Perilaku Makan Orang Tua Terhadap Kejadian Picky Eater (Pilih-Pilih Makanan) Pada Anak Toodler Di Desa Karang Jeruk Kecamatan Jatirejo Mojokerto". Medica majapahit. vol 5. No. 2, Oktober 2013

3. Hasan, Nurhayati. (2012). "Hubungan Pola Asuh Dengan Perkembangan Motorik Anak Usia 2-5 Tahun Di Posyandu Jakung Desa Jogoroto Jombang". KTI Ahli Madya tidak dipublikasikan. Politeknik Kesehatan Majapahit Mojokerto

4. Djamarah, Syaiful Bahri. (2014). Pola Asuh Orang Tua Dan Komunikasi Dalam Keluarga. Jakarta : Rineka Cipta.

5. Yusuf, Hajrah. (2013). "Pengaruh Pola Asuh Orang Tua Terhadap Tingkat Kooperatif Anak Usia 3-5 Tahun Dalam Perawatan Gigi Dan Mulut". Skripsi Sarjana Kedokteran Gigi yang dipublikasikan. Universitas Hasanuddin MakassarSumitro. (2006). Pola Asuh Kombinasi Cara Mendidik Anak Yang Lebih Baik.

(https://creasoft.wordpress.com/2 009/02/02/pola-asuh-kombinasicara-mendidik-anak-yang-lebihbaik-2/, diakses 20 Maret 2015) 